\title{
ENABLING LEGISLATION FOR NON-PROFIT HOSPITAL SERVICE PLANS
}

\author{
C.' Rupus ROREM*
}

Hospital bills have always been hard to pay. Hospitalization is relatively more expensive than other health service, it is often unpredictable, it requires absence from gainful employment, and it is usually accompanied by other expenses for professional service. Consequently, the hospital bill is peculiarly an economic hazard of the type which might be removed by insurance.

\section{Economic Aspects of Hospital Service}

The public attitude toward the costs of health service, particularly hospitalization, differs from the attitude toward loss of property or income. For centuries, society has held the position that a person is entitled to necessary health service regardless of his ability to pay. Before the days of hospitals and medical specialties, a rough-and-ready justice was obtained by the family physician, who charged his patients according to their real or presumed "ability to pay." With the development of specialized services and equipment for diagnosis and treatment, the personal benevolence of the family doctor was supplemented by the impersonal procedures of government taxation and organized philanthropy.

Hospital care has never been considered a private commodity, to be withheld from persons unable to pay. More than $70 \%$ of the million hospital beds in America are in government hospitals, and $25 \%$ more are in non-profit hospitals built through charitable contributions. In any one year, about $30 \%$ of the patients hospitalized for acute illnesses receive care free of cost to themselves, and another $20 \%$ pay less than the regular charges for hospital care. The ratios of free service are higher in the larger cities.

Since hospital care is not a private commodity, it has been difficult to interest the general public in private insurance against hospital bills. Hospitalization is a type of social service; hence hospitalization insurance has been regarded as basically a form of social insurance.

The average man knows that he is entitled to receive the necessary care regardless of his ability to pay at the time of sickness. But many employed persons of limited means dislike the "means test" for free or part-pay hospitalization, and have made

* A.B., I916, Oberlin College; A.M., 1925, Ph.D., 1929, University of Chicago; LL.D., 1935, Yankton. College. C.P.A., 1923, Indiana. Director, Commission on Hospital Service, American Hospital Association. 
valiant attempts to purchase the care as private patients from their own resources. Such persons have welcomed a contributory plan by which, through equal and regular periodic payments, they may budget their hospital service along with other necessities. Likewise, hospital administrators and trustees have accepted this method of helping to regularize hospital income.

\section{Origins of Hospital Service Plans}

Ten years ago a hospital service plan was established by Baylor University Hospital in Dallas, Texas, an experiment with 1500 school teachers which began a movement that has grown to $5^{6}$ city-wide and state-wide plans approved by the American Hospital Association, with 5,000,000 members. The success of the Baylor experiment derived from the fact that the hospital provided services rather than cash indemnities to the subscribers. Many of these subscribers might have received service free or at a discount. In any event, the $\$ 6$ annual subscriptions provided sufficient money to reimburse the hospital adequately for all care to the patients among the subscribers to the insurance plan.

Apparently the department of insurance of Texas did not consider that Baylor Hospital was engaged in the "insurance" business, but looked upon the procedure as a group contract for the sale of services by the hospital to the subscribing members. Similar one-hospital plans were initiated with reasonable success in New Orleans, Fort Worth, Memphis, and other cities. The resulting competition among hospitals and the desire of many subscribers to choose their hospital at time of illness rather than at time of enrollment, led to consideration of free-choice hospital service plans. Such plans were soon in operation at various places in the country. During 1932 and 1933, free-choice plans were begun in Sacramento, California, Bluefield and Charleston, West Virginia, Newark, New Jersey, and St. Paul, Minnesota. Steps had been taken for similar plans in New Orleans, New York City, Cleveland, and Washington, D. C. Several of these new plans instituted plans for dependent coverage at family rates, ranging from $\$ 1$ to $\$ 2$ per family, depending on type and degree of protection.

\section{The New York State Enabling Act}

A number of state departments of insurance had ruled that hospital service contracts, even if issued by one hospital, were a form of insurance and that hospital service policies could be issued only by stock and mutual insurance companies which met the established requirements as to capital stock, reserves, and assessments. The issue came to a head in New York and in Ohio during r933. The United Hospital Fund of New York wished to form a hospital service association which would contract for the provision of service in metropolitan hospitals to groups of persons making regular subscriptions to the association. The Cleveland Hospital Council had similar plans under way.

The New York state superintendent of insurance advised that such a function, although desirable, could be performed only by a stock or mutual insurance company. 
New York civic leaders, hospital administrators and trustees, and physicians cooperated in drafting and sponsoring an enabling act, which became a law May 16, $1934 .^{1}$ This New York law was the first of a series of 24 enabling acts which have been passed to permit the establishment of non-profit hospital service corporations. Because its provisions were soon incorporated, in whole or in part, in other state legislation, they may be summarized briefly at this point.

The first section (\$452), "Definition and Scope of Article," stated that "any corporation heretofore or hereafter organized under the membership corporation laws of the State of New York for the purpose of establishing, maintaining and operating a non-profit hospital service plan ... shall be governed by this article and shall be exempt from all other provisions of the insurance law of this state, unless specifically designated herein. ..." A non-profit hospital service plan was defined as a plan "whereby hospital care may be provided by the said corporation or by a hospital with which it has a contract for such care ... to such of the public who become subscribers to said plan under a contract which entitles each subscriber to certain hospital care." There was no restriction on the number or type of contracting hospitals, except that they must be "maintained by the state or any of its political subdivisions, or maintained by a corporation organized for hospital purposes under the laws of this state, or such other hospitals as shall be designated by the state department of social welfare."

The next section (\$453), "Incorporation," stated that each certificate of incorporation must be approved and filed in accord with the membership corporations law, and carry written evidence of the "consent of the superintendent of insurance of the State of New York and the state department of social welfare." There was a provision that "at least a majority of the directors of such corporation must be at all times directors or trustees of hospitals ... which have contracted or may contract with such corporation to render to its subscribers hospital service." (Italics added.)

Section 454, "Contracts," limited the corporation to entering into contracts with hospitals of the type described in Section 452, and referred to rates charged to subscribers and paid to hospitals. "(2) The rates charged by such corporation to the subscribers for hospital care shall at all times be subject to the approval of the superintendent of insurance.... (3) All rates of payments to hospitals ... shall be approved prior to payment by the state department of social welfare." (Italics added.)

The next four sections contained brief general statements for the regulation of the business and finances of the hospital service plans. Section 455 provided for annual reports to be filed with the superintendent of insurance "which shall be in such form and shall contain such matters as the superintendent shall prescribe." Section $45^{6}$ covered examinations, and gave the superintendent of insurance powers to visit and examine the books, papers, and documents, which were similar to those exercised over stock and mutual insurance companies. Acquisition costs were made "subject

\footnotetext{
${ }^{I}$ N. Y. Laws 1934, c. 595, adding Article $14, \$ \$ 452-46 \mathrm{r}$, to the New York Insurance Law. The 1939 legislature adopted a new codification of the Insurance Law, effective June 15, 1939, in'which Article IX-C, $\$ \$ 250-259$, was substituted for Article I4, broadened to include non-profit medical indemnity corporations, and amended in other respects.
} 
to the approval of the superintendent of insurance" by Section 457 , and funds were required by Section $45^{8}$ to be "invested only in securities permitted by the law of this state for the investment of assets of life insurance companies."

Section 459 provided that disputes between the corporation and contracting hospitals "may be submitted to the department of social welfare for its décisions..." and the decisions of the superintendent of insurance or the department of social welfare were made subject to revision "by proper proceedings in a court of competent jurisdiction." Section 460 stated that any dissolution or liquidation "shall be under the supervision of the superintendent of insurance," with all powers granted in respect to insurance corporations generally.

Every corporation operating a non-profit hospital service plan and subject to the above provisions of the insurance law was declared by Section $46 \mathrm{r}$."to be a charitable and benevolent institution, and all of its funds shall be exempt from every state, county, district, municipal and school tax, other than taxes on real estate and office equipment."2 (Italics added.)

On the basis of this law, Associated Hospital Service of New York began operations May r, r935, followed by the Rochester Hospital Service Corporation in June, x935. Other plans were soon organized in Albany, Buffalo, Geneva, Jamestown, Syracuse, Utica and Watertown. These nine plans now serve the entire state and, on July r, r939, had a total membership of 2,000,000 persons.

\section{Enabling Acts in Other States}

Following the lead of New York, 23 additional states (and Manitoba) have passed special enabling acts for non-profit hospital service plans, bringing them under the departments of insurance and in some instances also the departments of health or welfare. The dates of passage ${ }^{3}$ for all enabling acts ${ }^{4}$ were as follows: 1934-New York; I935-Alabama, California, Illinois; I936-Mississippi; ${ }^{5}$ I937-Georgia, Maryland, Massachusetts, Pennsylvania; 1938-Kentucky, New Jersey; I939-Connecticut,

\footnotetext{
2 One brief section amended the membership corporation law by requiring the secretary of state to obtain consent from the departments of insurance and welfare before filing a certificate of incorporation for any service plan. The final section declared that "this act shall take effect immediately."

The lowa, Michigan, and Wisconsin acts were passed in 1939 after bills had been defeated in 1937.

-New York: supra note I; Alabama: Acts 1935, act no. 544, am'd, Acts 1936 (Ext. Sess.) act no. 169, Acts, 1939; California: Stat. 1935, c. 386, am'd, Stat. x937, c. 88x, Stat. 1939, A. B. I712; Illinois: REv. Stat. (1937) \$551-562; Mississippi: Laws 1936, c. 177; Georgia: Laws 1937, no. 379, p. 690; Maryland: Laws 1937, c. 224; Massachusetts: Anv. Laws (1938 Supp.) c. 176A; Pennsylvania: Stat. Anv. (Purdon, 1938) tit. 15, c. 49A, \$\$2851-1301-285I-1309; Kentucky: Acts 1938, c. 23; New Jersey: Laws 1938, c. 366; Connecticut: Laws 1939, S. B. 51; District of Columbia: S. B. 497, 76th Cong. Ist Sess. (1939); Iowa: Laws 1939, c. 222; Maine: Laws 1939, c. I49; Michigan: Laws 1939, H. B. I45; New Hampshire: Laws 1939, H. B. 232; New Mexico: Laws 1939, c. 66; Ohio: Laws 1939, S. B. 181; Rhode Island: Laws I939, c. 719; South Carolina: Acts 1939, H. B. 845; Texas: Laws 1939, Subst. H. B. I91; Vermont: Laws 1939; Wisconsin: Laws 1939, S. B. 288.

In subsequent references to enabling acts cited in this note these statutory citations will not be repeated.

'The Mississippi act, supra note .4 , does not require plans to be non-profit corporations. It provides "for the organization and regulation of hospital service associations," organized as capital stock corporations with a minimum of $\$ 10,000$ paid-in capital. The law was sponsored by the state medical and hospital associations.
} 
District of Columbia, Iowa, Maine, Michigan, New Hampshire, New Mexico, Ohio, Rhode Island, South Carolina, Texas, Vermont, Wisconsin.

The 24 states have a total population of $88,000,000$, based upon the I935 census estimates. Not all of them have hospital service plans in operation under the enabling acts. Those without active plans in September, r939, were Iowa, New Hampshire, New Mexico, South Carolina, Texas, Vermont, and Wisconsin.

Nine other states have ruled, through their attorneys general or departments' of insurance, that non-profit hospital service plans are not "insurance" and have permitted them to operate under the general corporation laws, exempt from the regulations covering stock and mutual insurance companies. These states are: Colorado, Delaware, Louisiana, Minnesota, Missouri, North Carolina, Tennessee, Virginia, West Virginia. The executives and trustees of service plans in Minnesota, Tennessee, and West Virginia initiated legislation in 1939 to give them insurance department supervision, but in each case the bill was lost in committee or upon vote of the legislature.

The other 16 states of the union presumably require that hospitalization insurance may be supplied only through stock and mutual insurance companies, regardless of whether benefits are supplied as cash indemnity or hospital service.

\section{Origins of Hospital Agency Contracts}

Late in 1933, when enabling legislation was under consideration in New York, the insurance commissioner of Minnesota required the St. Paul Hospital Service Association to rewrite the contracts with hospitals in such a way as to make the association the agency for the member hospitals. ${ }^{\circ}$

Early in the year 1934, the Hospital Council of Cleveland was completing the administrative details for a hospital service plan under the non-profit laws of Ohio. Attorneys for the Council proposed to establish the hospital service association as the agent of the hospitals, severally and jointly, and argued that such an arrangement would remove the activities from the field of insurance according to the laws of Ohio. Before the merits of the case could be tested, there was discovered in the General Code, Section 669, passed in 1903, a statement which specifically authorized the proposal being made. ${ }^{7}$

This act, adopted thirty years previously, did not permit the associations to offer contracts to non-residents of the county in which the association and hospitals were located. But it sufficed to authorize establishment of the Cleveland Hospital Service

'Stated in depositions submitted in evidence in Currie and Schlief v. Minnesota Hospital Service Ass'n, a case now pending in District Court, Ramsay County, Minnesota.

${ }^{7}$ Onto Gen. Code' (Page, 1937) \$669, prior to amendment in 1939, reads as follows: "No law of this state pertaining to insurance shall be construed to apply to the establishment and maintenance by individuals, associations or corporations of sanitariums or hospitals for the reception and care of patients, for the medical, surgical or hygienic treatment of any and all diseases, or for the instruction of nurses in the care and treatment of diseases and in hygiene, or for any and all purposes, nor to the furnishing of any or all such service, care or instructions in or in connection with any such institution, under or by virtue of any contracts made for stuch purposes, with residents of the county in which such sanitarium or hospital is located." (Italics added.) 
Association in July, r934, and later plans in Akron, Toledo, Youngstown, Canton, Newark, Columbus and Portsmouth. An amendment to Section 669 was passed in I939 which brought non-profit hospital service plans within the supervision of the department of insurance and removed the county-line limitation.

\section{Hospital Responsibility Under Enabling Acts}

When the Cleveland Hospital Service Association was launched in I934, the "inter-hospital agency contract" established the hospitals as the principals in the contractual obligations for expenses of the plan and services to the subscribers. The hospitals agreed to accept flat rates per day for services to subscribers, or such pro rata payments as the available funds permitted. In addition, they agreed to fulfil all contracts until the end of the contract year, and, if necessary, to refund payments to the association to cover necessary operating expenses. This principle of hospital responsibility was expressly recognized in several enabling acts, the first being that passed by the Maryland Legislature in. 1937, which read as follows: "Each contract executed ... by the applicant with any hospital for the furnishing of service to the subscribers to the hospital service plan obligates . . . each hospital party thereto to render the service to which each subscriber may be entitled."

During the year I939, similar provisions appeared in the enabling acts of Maine, Michigan, Ohio, and South Carolina. Other state insurance departments have required that hospital contracts be drawn in such manner as to relieve the subscriber from the possibility of assessment or failure to receive care in case of any temporary or long run difficulties of the corporation to pay the agreed rates to hospitals or other expenses.

\section{Need for Administrative Regulation}

The original New York enabling act gave wide discretionary powers to the state Superintendent of Insurance and the State Department of Social Welfare. The California and Illinois laws passed in 1935 followed almost identically the wording of the New York bill. As a guide to the'New York plans, the Department of Insurance issued a letter, during the summer of 1937 , with suggestions intended to protect the interests of the subscribers and the associations. ${ }^{8}$ These-included, among other suggestions: freedom of subscriber from the requirement of paying his complete annual dues at time of illness, equal payments to non-member hospitals in emergency cases, non-cancellable policies within a year. The Department of Social Welfare also indicated certain general policies as the basis of approval of the certificate of incorporation. These included: evidence of need as indicated by the general population and the number of other associations, the character and standing of the incorporators, adequacy of working capital at time of organization.

As new enabling acts were passed from I937 to I939, they carried more specific

${ }^{8}$ Cited by Carl Metzger of Buffalo in paper on "Laws Governing Group Hospitalization in New York State." Mr. Metzger s paper and similar papers by Ray F. McCarthy of St. Louis and J. Philo Nelson of Oakland, California, mentioned the development of regulations in the various states. The papers were printed by the American Hospital Association as Special Meeting of Group Hospital Service Plan Executives, Atlantic City, N. J., Sept., 1937. 
provisions and defined the rights and powers of the state regulatory bodies as well as the obligations of the plans as to form of organization, public policy, accounting and administrative procedures, hospital responsibility, financial solvency, investments, etc. The Commission on Hospital Service and Council on Hospital Service Plans of the American Hospital Association attempted to place the best features of these regulations into a model enabling act which was prepared for distribution in 1938 , and which influenced the legislation in several states during the 1939 sessions. This complete "model bill" appears as Appendix A to this article. There were some desirable standards for the administration of a successful non-profit hospital service plan which did not seem appropriate for inclusion in the laws of the various states. Many of these appear in the Standards for Non-Profit Hospital Service Plans used as the basis for approval by the Commission on Hospital Service. The complete standards appear as Appendix $B$ to this article.

Certain features tend to be characteristic of all the enabling legislation. Other special phases differentiate some of the bills from all others. An attempt will be made to summarize the most important of the common features, as well as some of the unique aspects of the various enabling acts.

\section{Hospital Service Plans as Insurance}

Most of the enabling acts open with a statement that hospital service corporations are "exempt from all provisions of the insurance code of this state not otherwise specifically designated therein." This was the original wording of the New York act, and was followed in a number of states, for example, Iowa, Illinois, Kentucky. The Pennsylvania Act states that such corporations "shall be subject to regulation by the Department of Insurance as provided in this Act." The same result is obtained with different wording in the laws of Georgia and Texas, each of which states that "hospital service corporations shall be governed by this act, and shall not be construed as being engaged in the business of insurance under the laws of this state."

From the economic point of view, hospital service plans are a form of insurance. From the provisions of the various state regulations and the enabling acts, it appears that they constitute a special type of insurance differing from the stock and mutual companies.

\section{Exemption from Taxation}

The original New York law provided that the hospital service plans were to be exempt from "every state, county, district, municipal and school tax, other than taxes on real estate and office equipment." This general formula was followed elsewhere, notably District of Columbia, Illinois, Maryland, New Jersey and California. When the New York Enabling Act was amended in 1939 as Chapter 28, Article IX-C, of the Consolidated Laws, the tax exemption was extended to "every state, county, district, municipal and school tax." The same general rule is applied in the states of Alabama, Connecticut, Georgia, Iowa, Massachusetts, Maine, Michigan, New Mexico, Ohio, Pennsylvania, Rhode Island, South Carolina, Texas, Wisconsin. 
Non-profit hospital service associations have been ruled exempt from federal income taxation, provided they meet the requirements of an "organization for social welfare," as described in Section Ior(8) of the Revenue Act of 1936. Rulings by the Bureau of Internal Revenue have been made with regard to a number of the hospital service plans. Directors or trustees of each plan have followed the advice of legal counsel and submitted the required evidence for consideration by the income tax unit. But non-profit hospital service associations have been ruled not exempt from liability for social security tax provisions. They are not classified as "charitable organizations" under Title IX, Section 907 (c), of the Social Security Act, and executives are required to file returns and make contributions on the same bases as other corporations. In states where enabling acts have not been passed, the various non-profit plans have been exempt from capital stock and corporate taxes not assessed against other charitable and benevolent institutions.

\section{Investment of Funds}

Practically all of the enabling acts require that the funds of the corporation shall be invested only in securities permitted by laws of the state for the investment of the assets of "life insurance companies." This was the original New York regulation and was continued in the 1939 amendment. Other states which have this restriction are Illinois, Iowa, Kentucky, New Jersey, Maryland, Michigan, New Mexico, Ohio, Pennsylvania, and South Carolina. The New England states register a departure from this regulation, with Maine, New Hampshire, and Vermont restricting the assets in accord with those recognized as legal investments for "savings banks." Massachusetts restricts investments to those for "insurance companies," and Connecticut applies the same restrictions as for "trust funds," excepting real estate mortgages.

\section{Composition of Board of Directors or Trustees}

The original New York law required that a majority of the board of directors or trustees must be represenitatives of hospitals with which the corporation had contracts for service to subscribers. This feature was removed in the 1939 amendment of the New York law, but appears in various modifications in a number of the other enabling acts passed during the past five years. The following states include in their enabling acts a requirement that "at least a majority" of the directors of the corporation must be administrators, trustees, or members of the clinical staffs or advisory boards of the member hospitals: Georgia, Iowa, New Jersey, Maine, Ohio, Rhode Island, and Texas. The Illinois law requires the majority of the board to be hospital representatives and medical or dental practitioners. In California, two thirds of the board of directors must be composed equally of representatives of contracting hospitals and qualified practicing physicians in the state of California.

The new enabling acts for Michigan and South Carolina call for representation from the general public, the hospitals, and the medical profession.. The law for the District of Columbia requires that one third of the trustees shall be appointed by the 
Commission of the District of Columbia, one third by the Medical Society, and one third by a group representing the hospitals.

A special feature of the Iowa requirement is that the board of directors shall consist of at least nine members, not more than one being from any one hospital. This means, of course, that no plan can be placed in operation until nine hospitals are enrolled as member institutions. A somewhat different guaranty that the plans will serve relatively large communities is derived from the Wisconsin requirement that the member, hospitals must be not less than six, and have a total bed capacity. of not less than 600 .

\section{Eligibility of Hospitals}

The typical requirement for elígibility for a hospital to serve as a contracting institution is "approval" by some state regulatory body, usually the state department of health or social welfare, although in some states, such as Maryland, the insurance departments exercise the full authority. In Connecticut the Medical and Homeopathic Examining Boards submit the list of approved hospitals. Most of the plans state explicitly that contracts may be entered into with hospitals maintained "by the state or any political subdivision, or maintained by a corporation organized for hospital purposes under the laws of this state, or other hospitals approved by tha state department of welfare."

The Kentucky law makes no provision for unincorporated hospitals. The Ohio law is limited exclusively to non-profit institutions, and proprietary institutions are not eligible for participation. The South Carolina law requires contracting hospitals to hold membership in the South Carolina Hospital Association. The 1939 revision of the New York law permits hospitalization contracts with "hospital service plans and hospitals of other states, subject to the supervision of other states." In Alabama, member hospitals must have the approval of the Alabama Hospital Association and the State Board of Censors of the Alabama Medical Association. In Georgia, a member hospital must be recommended by "the State Board of Health or the Medical Association of Georgia, or the Georgia Hospital Association, or the County Medical Society."

The Ohio law states explicitly that services may be provided in other than member hospitals in case of emergency. The Georgia and Texas acts assume that benefits may be provided in non-member hospitals, requiring that the certificates state "the rate per day or week payable by said corporation for hospital services rendered to said member at any hospital other than the hospitals with which said corporation shall have contracted."

\section{Rates to Subscribers and to Hospitals}

All of the enabling acts require that the rates charged to subscribers be subject to approval by the state departments of insurance. A number of the acts (New York, New Jersey, Connecticut) state that such subscription rates may be refused approval 
by the insurance commissioner if he finds them "excessive, inadequate, or unfairly discriminatory."

The rates of payments to the hospitals are, in some instances, subject to approval by some agency other than the department of insurance, such as the Departments of Social Welfare in New York and Illinois, and the Department of Institutions and Agencies in New Jersey. A provision of the revised 1939 act in New York carries the following statement with regard to rates paid to hospitals: they must be "approved as to adequacy by the commissioner of social welfare and as to reasonableness by the superintendent of insurance."

\section{Examinations and Reports}

Each of the various acts contains a requirement relating to the examination of the assets, liabilities, and methods of conducting business, and all other affairs of the corporation. These matters may be investigated whenever the insurance departments of the states deem it expedient, and the expenses of such examination must be borne by the corporation. New Mexico requires that not more than $\$ 10.00$ per day, or a maximum of $\$ 100$, plus expenses, may be charged for each examination. Rhode Island raises the maximum to $\$ 200$.

All of the enabling acts require that reports shall be made annually in such form as the Departments of Insurance "shall prescribe."

\section{Working Capital, Reserves, and Surplus}

The more recently enacted enabling acts make definite recommendations as to the amount of working capital, reserves, and surplus which must be maintained by non-profit hospital service corporations. Some also place restrictions on the proportions of the earned income which may be used for administrative or overhead expenses.

The 1937 Maryland act carries the statement that the amount of money actually received for working capital must be sufficient to carry all acquisition costs and operating expenses "for a period of at least three months from date of issuance of the certificate." The Michigan law, passed two years later, states that the amount must be sufficient for a "reasonable length of time from the date of the issuance of the certificate of authority, and is not less'than the sum of $\$ 10,000 . "$ Maine sets a minimum requirement of $\$ 5,000$. Under the Ohio law, the corporation must have a cash surplus of at least $\$ 1,000$ at the time of beginning operations.

The Michigan and Maryland laws both prescribe "that the amounts contributed as working capital of the corporation are repayable only out of earned income over and above operating expenses and hospital services," as well as the reserves necessary to insure maturity of the contracts. The Alabama law requires that bonds be placed on deposit with the Insurance Commissioner, with a minimum of $\$ 3,000$ and a maximum of $\$ 20,000$, based upon the annual earned income.

The New Jersey and the recently amended New York laws stipulate that each corporation must maintain a special "contingent surplus" over and above reserves 
and liabilities. This surplus must be accumulated at the rate of $2 \%$ annually of the net premium income after the first year for a period of four years. The New York statutes change the rate of $2 \frac{1}{2} \%$ after this period, until a maximum of $\$ 100,000$ is reached; however, if the net premium income for the previous five years was less than $\$ 1,000,000$, a contingent surplus of $55 \%$ of the average annual premium may be maintained.

A number of states have now established maximum amounts which may be used for acquisition and administration expenses. The California law limits the amount to $25 \%$ of the earned income. The Texas act restricts the amount of the administrative expenses to $15 \%$ of the dues, subject to the authorization or approval of the Board of Insurance Commissioners. The New Jersey and New York laws set a maximum of $20 \%$ for administrative expenses not including expenses directly connected with the furnishing of benefits during each year of operation, and maximums of $20 \%, 15 \%$, and $10 \%$ for solicitation during the first, second, and third years, respectively.

By implication, each of the laws declares a plan to be "insolvent" and subject to liquidation or rehabilitation if unable to fulfil outstanding contracts and liabilities and to maintain the reserves required by law. A question arises as to whether or not contracts are adequately fulfilled when arrangements are made for reductions of rates in the payments to hospitals. Apparently an adjustment of rates with hospitals fulfils the legal obligation from the standpoint of the insurance departments, and restores the financial position of the plan, even though the reduced payments may never be completely recovered by the hospitals.

\section{Limitations On Hospital Service}

Most of the enabling acts state that hospital care is to be provided through the hospitals with which contracts have been drawn. Several of the enabling acts indicate that medical service shall not be included. The Michigan bill states that hospital service "shall be limited to hospital care such as bed, board, use of operating room, ordinary medications, surgical dressings, and general nursing care. Nothing in this act shall be construed as to permit a hospital or other corporation to engage in the practice of medicine in violation of Act 237 of the Public Acts of 1899 . . . or to contract to furnish the services of a physician for subscriber."

The Alabama act reads as follows: "the service therein provided shall not include any medical or surgical services." The Georgia and Texas laws carry identical statements: "The corporation shall not contract to furnish to the member a physician or any medical service, nor shall corporations contract to practice medicine in any manner." The Wisconsin act states that the contract "shall provide for hospital services only, and shall not embrace medical services." The California statute prescribes that medical services may be included in the benefits, in the following statements: "Hospital services may include ... indemnification of the beneficiary or subscriber for the cost and expense of professional medical service rendered during hospitalization." 
By and large, the terms "hospital service," "hospital care," and "hospitalization" are interpreted to mean those services ordinarily rendered by the contracting hospitals. This question came to a legal test in Pennsylvania during the summer of 1938 , when the County-Medical Society objected to the issuance of a charter to Associated Hospital Service of Philadelphia by the Court of Common Pleas, under the enabling act for hospital service plans. The County Medical Society maintained that the provision of certain medical services in the hospital service plan benefits (X-ray, laboratory, anesthesia, basal metabolism tests, electrocardiograms, and physiotherapy) exceeded the intent of the enabling act, which was to provide "hospitalization" and constituted the illegal practice of medicine by the hospitals, in contravention of statute. ${ }^{2}$ The issue of compliance with the enabling act in the application for charter was placed before a Special Master for report to the County Court.

Evidence was submitted to show that the provision of medical services by hospitals to subscribers of hospital service plans was consistent with the existing practice of providing such services to the private patients of the contracting hospitals. Attorneys for the service plan did not argue that the services mentioned were not medical services, but merely that the law contemplated permission to furnish these services when "a part of" hospitalization. The issue of the illegal practice of medicine by the hospitals was placed before a Special Master for report to the County Court. Before the evidence was completed, the County Medical Society withdrew the objections to the charter, upon the agreement that the Charter would refer to these services as "incident to" rather than "a part of" hospitalization.

In discussing the merits of the case, the Master said: "It is apparent that the hospital does not agree to perform any of these services, but merely to furnish facilities whereby they may be performed for the benefit of the patient; and no change is made, or contemplated, by the amended plan which will in any way alter the present relationship between the hospital, the patient and the doctor performing the services." In another place he said: "In the opinion of the Master, there is no agreement on the part of any one to 'practice medicine.' It is indemnification to the patient for at least a part of the costs of these services, and nothing more."10

\section{Hospital Responsibility}

Mention has been previously made of the requirement in certain enabling acts that a direct obligation be assumed by the hospitals with which the hospital service corporation has contracted. Originally the agency contracts in New York were drawn in such manner as to make the hospital contract and the subscriber contract cancellable on short notice-in the case of the New York City plan, thirty days. Upon recommendation of the Departments of Insurance, a number of the plans changed their contracts so that the hospitals and the plan assumed their obligations for a twelve-month period. Conversely, the corporation was not permitted to promise

\footnotetext{
${ }^{\circ}$ Pa. Stat. Ann. (Purdon, 1938) tit. 63, c. 10, $\$ 401$.

${ }^{10}$ Master's Report, In re Application for Charter of the Associated Hospital Service of Philadelphia, Common Pleas No. 7, March Term, 1938, No. 3470.
} 
benefits more than twelve months in advance. These features were later included in the New Jersey and New York acts, with the statement that contracts may be written with the provision that they would be renewed from year to year unless there was one month's prior written notice of termination given by either the subscriber or the corporation.

The Connecticut, New York and New Jersey laws provide that no contract shall entitle more than one person to services, except a family contract "to a husband and wife, or husband, wife and their child or children not over eighteen years of age." Family contracts are, of course, regularly issued in most of the states, but these revised laws bring them exclusively within the province of the enabling acts.

\section{Special Provisions}

A number of special provisions are of sufficient interest to mention, although they do not appear in the enabling acts of a large number of states. A few will be cited. The acts do not affect the liability of an employer under the provisions of the Workmen's Compensation Law. This is specifically mentioned in Connectitut, New York, New Hampshire, and Vermont. The Connecticut, New York and New Hampshire laws state that fraternal benefit societies are not affected by the acts. New Hampshire forbids a hospital service corporation from any other state or country to be licensed in New Hampshire. The New Jersey and New York laws both permit local plans to operate in other states. The Connecticut law provides that plans "may merge." The Alabama act requires that a hospital service corporation pay the same amount to a hospital outside of Alabama as to one within the state. The Wisconsin enabling act carries a unique statement of public policy as a preamble to the provisions of the administration of the law. ${ }^{11}$

The New York law permits the Insurance Commissioner to refuse a charter if he considers the incorporation "contrary to the interest of the people." The Rhode Island Commissioner is to base his' decision on "public convenience and advantage." The Ohio Superintendent of Insurance must be satisfied that the proposed plan is "established upon sound actuarial and financial bases, in view of the experience of non-profit hospital service plans already in existence."

The Rhode Island law does not permit the solicitation of subscribers on a commission basis, or any basis where the compensation is conditioned upon enrollment of subscribers, unless the method of solicitation and rate of compensation shall have received written approval by the Chief of the Division of Banking and Insurance.

${ }^{11}$ Wis. Laws 1939, S. B. 288, §1: Public Policy: As a guide to the interpretation and application of this section, the public policy of this state is declared to be: to ease the burden of payment for hospital serviecs, particularly in the low income groups, where with the advance of scientific methods the payment for adequate hospital services is a pressing problem with grave social ramifications, non-profit hospital service corporations, based on the tested experience in many parts of the United States, economically sound, socially beneficent, are needed.

While in no way changing the present status of voluntary hospitals in the state, these corporations will enable a larger number to procure for themselves adequate hospital services and leave the use of the free and part free services given by the hospitals to those whose economic status makes self-procurement of such services impossible. Without imposing the burden on the public treasury and free from any motive of profit, these corporations will contribute to the solution of a pressing social and economic problem in the state and merit the support of the citizens. 
The New Hampshire law requires that "all benefits are payable to the hospital." The Texas law states that corporations shall not pay any funds collected from subscribers to any hospital "until after care has actually been rendered."

A special provision in Michigan permits the corporation to "receive and accept a lump sum or per capita sum from governmental or private agencies," associations or groups in payment of subscriptions of persons or groups of persons in need of hospital care who cannot pay the cost of the subscription.

In Ohio, each plan must pay a fee of $\$ 250$ at time of formation, and an annual fee equal to one mill for each contract issued and outstanding as of the ist of March each year. In Texas, no compensation may be paid "in excess of $\$ 6,000$ per year" to any employee, and all salaries are to be approved by the board of Commissioners. In Massachusetts, all salaries of $\$ 5,000$ or more must be approved by the board of directors of the plan.

The enabling act of Vermont makes the act apply not only to hospital service plans, but also to those furnishing hospital, medical, surgical, or nursing service. The New York law as amended in 1939 applies to "non-profit medical indemnity corporations." Group Hospitalization, Inc., of the District of Columbia is authorized to "cooperate, consolidate, or contract" with groups or organizations interested in promoting and safeguarding the public health. The Texas law makes specific provisions that "officers or directors may be allowed reasonable and necessary expenses" for five meetings of the'corporation per year. A number of the acts require that all persons who solicit, receive, or procure applications must be "licensed" by the Superintendent of Insurance of the state under which the plan is chartered.

\section{The Commission On Hospital Service}

The Commission on Hospital Service of the American Hospital Association was formed in 1937 for the study and development of hospital care insurance and related problems of hospital finance. It is financed separately from the general activities of the American Hospital Association, in part by a grant from a philanthropic foundation and in part from contributions by plans toward a Research Program of the Council on Hospital Service Plans, organized within the Association.

The Commission issues approval certificates for non-profit hospital service plans which meet certain standards. In states where special enabling acts have been passed, hospital service plans must be organized under such laws. The Commission neither approves nor disapproves stock or mutual insurance companies, and exercises no legal control over the hospital service plans. The approval program is a supplement to, rather than a substitute for, the regulation of hospital service plans by state insurance bodies. The primary features of the standards for approval are (I) the clear establishment of the responsibility of member hospitals for services to subscribers and (2) financial status and operations which adequately protect the interests of subscribers and member hospitals.

The hospital responsibility requirement is not accidental; it is fundamental. Without such a guaranty, the plans would be less able to protect the interests of sub- 
scribers than a well-managed stock or mutual insurance company. In exchange for the hospital guaranty, the management of a plan owes it to member hospitals to conduct the affairs in such manner as to avoid the necessity of calling upon the guarantors. Suggestions for efficient administration are contained in the Standards adopted by the Commission as the basis for approval. These include non-profit organization, hospital responsibility, community representation, freedom of choice, adequate working capital, appropriate rates and benefits, accounting and statistical control, sound administrative procedures, and harmonious staff and hospital relationships.

Hospital service plans are not a panacea for the hospital or the public. Most of them have been established for semi-private rather than ward service plans, and they do not include the services of attending physicians and surgeons. The hospital service plans may be looked to as a guide in shaping a wise and administratively efficient national health program. The future of the voluntary hospitals is dependent upon the future of voluntary hospital care insurance. The service plans are an American approach to the problem of the uncertainty of sickness costs; they combine the advantages of individual initiative and social responsibility.

\section{APPENDIX A}

Proposed Model Law to Enable the Formation of Non-Profit Hospital Service Associations Under the Supervision of the Various State Departments of Insurance

Prepared by the Commission on Hospital Service and the Council on Hospital Service Plans of the American Hospital Association, January, 1939

I. Scope: Any corporation organized not for profit under the General Corporation Act of the State of ......... for the purpose of establishing, maintaining and operating a non-profit hospital service corporation, whereby hospital service may be provided by a hospital or group of hospitals with which such corporation has a contract for such purpose, to such of the public as become subscribers to said corporation under a contract which entitles each subscriber to certain hospital care, shall be governed by this act and shail be exempt from all other provisions of the insurance laws of this state, unless otherwise specifically provided herein.

II. Incorporation: The articles of incorporation of every such corporation, and amendments thereto, shall be submitted to the Department of Insurance, whose approval thereof shall be endorsed thereon before the same are filed with the Secretary of State; provided, however, that if the articles of incorporation of any such corporation shall have been filed with the Secretary of State prior to the effective date of this statute, the approval thereof by the Department of Insurance shall be evidenced by a separate instrument in writing filed with the Secretary of State.

III. Directors: The Directors of such corporation must at all times be composed of the following groups in such proportions as to give equitable representation: $(I)$ administrators or trustees of hospitals which have contracted with such corporation to rẹder hospital service to the subseribers; (2) licensed physicians, exclusive of group (I); (3) general public exclusive of -groups (1) and (2).

IV. Contracts: Such corporation may enter into contracts for the rendering of hospital service to the subscribers only with hospitals approved by the Department of Insurance or Departments of Health or Welfare. All contracts issued by such corporation to the subscriber shall constitute direct obligations of the hospital or hospitals with which such corporation has contracted for hospital service.

V. Rates: The rates charged to the subscribers for hospital service and the rates of payment by such corporation to the contracting hospitals, at all times shall be subject to the approval of the Department of Insurance.

VI. Application for Certificate: A corporation subject to the provision of this act may issue contracts only when the Department of Insurance has by formal certificate or license authorized it to do so. Application for such certificate of authority or license shall be made on forms to be supplied by the Department of Insurance, containing such information as it shall deem necessary. Each application for such certificate or license shall be accompanied by copies of the following documents: (a) certificate of incorporation; (b) bylaws; (c) proposed contracts between the corporation and participating hospitals showing terms under which hospital service is to be furnished to subseribers; (d) contracts to be issued to subscribers showing a table 
of the rates to be charged and the benefits to which they are entitled; (e) financial statement of the corporation, including the amounts of contribution paid or agreed to be paid to the corporation for working capital and the name or names of each contributor and the terms of each contribution.

VII. Issuance of Certificate: The Department of Insurance shall issue a certificate of authority or license upon payment of a fee of $\$ . . . . .$. and upon being satisfied on the following points:

(a) That the applicant is established as a bona-fide non-profit hospital service corporation.

(b) That the contracts between the applicant and the participating hospitals obligate each hospital party to render service to which each subseriber may be entitled under the terms and conditions of the contract issued to the subscribers.

(c) That the rates charged and benefits to be provided are fair and reasonable.

(d) That amounts provided as working capital of the corporation are repayable only out of earned income paid and payable for operating expenses and hospital expenses and such reserve as the Department of Insurance deems adequate.

(c) That the amount of money actually available for working capital be sufficient to carry all acquisition costs and operating expenses for a reasonable period of time from the date of the issuance of the certificate.

VIII. Reports: Every such corporation shall annually on or before the first day of March (or the first day of June) file in the office of the Department of Insurance a statement verified by at least twa of the principal officers of said corporation showing its condition on the 3Ist day of December, then next preceding, which shall be in such form and shall contain such matters as the Department shall prescribe.

XI. Visitation: The Department of Insurance may appoint any Deputy or Examiner or other person who may have the power of visitation and examination into the affairs of any such corporation and free access to all of the books, papers and documents that relate to the business of the corporation, and may summon and qualify witnesses under oath to examine its officers, agents or employees or other persons in relation to the affairs, transactions and conditions of the corporation.

X. Expenses: All acquisition and administrative expenses in connection with such hospital service corporation shall at all times be subject to the approval of the Department of Insurance.

XI. Investments: The funds of any corporation subject to the provisions of this act shall be invested only in securities permitted by the law of this state for the investment of assets of life insurance companies.

XII. Dispattes: Any dispute arising between a corporation subject to the provisions of this act and any hospital with which such corporation has a contract for hospital service may be submitted to the Department of Insurance for its decision with respect thereto. Any decision and finding of the Department of Insurance made under the provisions of this act shall not be any bar to constituted legal procedure in a court of competent jurisdiction.

XIII. Dissolution: Any dissolution or liquidation of a corporation subject to the provisions of this act shall be conducted under the supervision of the Department of Insurance which shall have all power with respect thereto under the provisions of law with respect to the dissolution and liquidation of insurance companies.

XIV. Taxation: Every corporation subject to the provisions of this act is hereby declared to be a charitable and benevolent institution, and its funds, operations and properties shall be exempt from taxation.

\section{APPENDIX B}

\section{Síandards for Non-Profit Hospital Service Plans}

Established by the Commission on Hospital Service of the American Hospital Association, January, 1938; revised September, 1939.

I. The corporate body should include adequate representation of hospitals, the medical profession, and the general public. Trustees or board members of the hospital service plan should receive no remuneration for service as trustees or board members. The interests and the responsibilities of participating hospitals make it desirable that a majority of the policy-making body be representatives of hospitals.

2. No private investors should advance money in the capacity of stockholders or owners. Initial working capital may be provided by individuals, hospitals, chests, councils or other civic agencies, but should be repayable only out of earned income, over and above operating expenses, payments to participating hospitals and legal reserve. No organizations or individuals advancing initial capital should attempt to influence or direct the management of hospital service plans because of their financial support. The hospital service plan should be independent of any other corporate body or professional or lay group.

3. Plans should be established only where needs of a community are not adequately served by existing non-profit hospital service plans. Opportunity should be given for all institutions of standing in each community to become member hospitals in a hospital service plan and subscribers should have free choice of hospital at the time of sickness.

4. The hospital service benefits of a non-profit hospital service plan should be guaranteed by the member hospizals during the life of the subscriber-contract. The ultimate economic responsibility for 
service to subscribers enrolled at any given time should be assumed by the member hospitals, through definite contractual agreements with the hospital service plan. All contracts involving the plan, the subscribers and the member hospitals should be equitable and consistent with respect to the rights and obligations of each party.

(a) Benefits in member hospitals should be expressed in "service contracts," which describe specifically the types and amounts of hospital services to which the subscribers are entitled.

(b) A majority of the hospitals of standing should be member-hospitals in cach area where a hospital service association enrolls subscribers, and arrangements should be made for provision of service in nonmember hospitals.

(c) In case of physical impossibility to provide service in member-hospitals or others, equitable arrangements should be made for protection of the subscribers' interests.

(d) It is understood that State legislation may require modifications of these requirements.

5. Subscription payments or dues received should be currently separated into "earned" and "unearned" income. The earned income should be apportioned to special accounts each earmarked for special purposes, as follows:

(a) Hospitalization: For payments to participating hospitals. Charges against this account should include estimated payments for undischarged cases. (Desirably 60 to 80 per cent.)

(b) Contingency Reserve: In minimum ratios determined by law, or larger proportions designated by action of board of trustees. (Desirably from 5 to ro per cent.)

(c) Field Service and Administration Expense: (Not exceeding 15 to 30 per cent.) The cumulative ratio of field service and administration expense to earned subseription payments or dues should not exceed 30 per cent for the first full year, and the monthly ratio should be considerably less by the cnd of the year. Ultimately the ratio should not exceed 15 per cent.

In the calculation of earned income from subscription payments or dues during a given fiscal period, only those cash receipts should be considered "earned" which apply to and are intended for the payment of hospital benefits and expenses during that period. When subscription payments or dues are received in advance of the fiscal period to which they apply, the "unearned" portion should be accurately determined and separately recorded in the accounting records.

The formulas for calculating unearned subscriptions established by the various State departments of insurance are, in general, acceptable to the Commission. Where a non-profit service plan is not supervised by the State Department of Insurance, the uniform procedure adopted by the Council on Hospital Service Plans is recommended. Details of this procedure can be obtained from the Commission on Hospital Service.

6. Statistics should be maintained currently as follows: (a) Number of subscribers (classified). (b) Number of hospital admissions (classified). (c) Number of patient days of care (classified). (d) Number of member-months (or member-years) of protection to subscribers (classified).

7. Initial working capital should be sufficient to carry all acquisition costs and operating expenses for a stated period (e.g., six months), after contracts first become effective, thus making earned income from subseriptions available in full for payments to hospitals during this period. Financial statements of operations and condition could be prepared by certified public accountants at regular intervals, at least annually.

8. The requirements for annual reapproval by the Commission shall be: (a) Maintenance of standards of organization and policies applied at time of original approval; (b) a substantial number of enrolled subscribers having in mind the possibilities of the area served; (c) a period of successful operation, with sound administrative procedures, usually not less than six months of enrollment activities; (d) financial status and operations which adequately protect the interests of subscribers and member hospitals.

9. Payments to hospitals should be based on the costs of services provided to subscribers in hospitals of that community, district or region. This does not preclude the possibility of developing public wardservice plans for employed groups with low incomes, and agreements by member hospitals to provide service at rates less than the full operating costs.

ro. Employees of a non-profit hospital service plan should be reimbursed by salary as opposed to a commission basis. A private sales organization should not be given responsibility for promotion or administration on the basis of a percentage of premiums. Promotion and administrative policies should be dignified in nature, consistent with the professional ideals of the hospitals concerned, and in accord with economically sound practices as determined by actuarial and financial experience of the various plans.

II, In communities with only one hospital, the finances of a hospital service plan should be scparate from the general budget of the hospital.

12. Hospital service provided through a hospital service plan should be determined by the practices of the member hospitals of the particular plan.

13. Hospital service plans should not interfere with existing relationships between physicians and hospitals or between physicians and patients.

14. A hospital service plan should mect with the general approval of the Commission on Hospital Service of the American Hospital Association. 